\title{
RESEARCH ON THE INFLUENCE OF SPORTS COMPETITIONS ON THE FORMATION OF PERSONAL QUALITIES OF STUDENTS-ATHLETES
}

\author{
Svetlana Cherevko' \\ orcid-0000-0003-3129-6599 \\ Anzhela Ploshynska ${ }^{2}$ \\ orcid - 0000-0002-4268-4434
}

Tetyana Globa ${ }^{3}$

orcid - 0000-0003-3442-4250

Anatoly Cherevko ${ }^{4}$

orcid - 0000-0002 1743-0547

\section{1-3 Oles Honchar Dnipro National University, Dnipro, Ukraine \\ ${ }^{4}$ University of Customs and Finance, Dnipro, Ukraine}

corresponding author - S. Cherevko: svetvikch@gmail.com

The article substantiates the possibilities of student sports, which is a generalized category of student activities in the form of competitions and preparation in order to achieve the ultimate results in the chosen specialization. Sports are a form of self-expression and self-affirmation of students that define their lifestyle, general cultural and socially significant priorities. The aim of the study. To study the influence of situations of sports competitions on the formation of personal qualities of students-athletes at higher educational institutions. Research methods. The following theoretical research methods are used: analysis, synthesis, classification, systematization; empirical methods: surveys, sociometry, statistical method of processing results. Results of the research. The indicators of professional achievements of studentsathletes at higher educational institutions were analyzed, which made it possible to determine quantitative and qualitative differences in sports achievements, as well as the influence of sports situations on the formation of personal qualities. The results of educational and sports activities in the formation of socially significant qualities are considered: social activity, independence, confidence in students' abilities. Conclusion. Student sport is a generalized category of student activity in the form of competitions and preparation in order to achieve extreme results in the chosen specialization. The result of educational and sports activities of students is the formation of socially significant qualities: social activity, independence, self-confidence, ambition. The formation of personal qualities of students of higher education during sports classes within the experiment is a set of conceptual provisions and the creation of appropriate pedagogical conditions. It is proved that the created pedagogical conditions, namely constant trainings and participation in competitions of different level promote increase of sports skill of participants of a team and development of personal qualities of students, favorable both for their big success, both in a certain kind of sport, and in any kind of activity in general.

Key words: personal qualities, student-athletes, sociometric status, level of anxiety, personality orientation, stress factor.

\section{Introduction}

With the further establishment of an independent Ukrainian state, among the various problems associated with the national system of physical culture and sports, the problem of increasing the spiritual potential of the nation, especially the younger generation, remains relevant. The ideal of humanity has always been a comprehensively developed personality in which spiritual, intellectual wealth, and physical perfection combine harmoniously [8, p.45]. doi: 10.32626/2309-8082.2021-20.5-10

Світлана Черевко, Анжела Плошинська, Тетяна Глоба, Анатолій Черевко. Дослідження впливу ситуацій спортивних змагань на формування особистісних якостей студентів-спортсменів

Анотація. У статті обґрунтовано можливості студентського спорту, який являє собою узагальнену категорію діяльності студентів у формі змагань і підготовки до них з метою досягнення граничних результатів у обраній спеціалізації. Заняття спортом виступають формою самовираження та самоствердження студента, визначаючи його спосіб життя, загально культурні та соціально значущі приорітети. Мета дослідження. Вивчення впливу ситуацій спортивних змагань на формування особистісних якостей студентів-спортсменів 3 ВО. Методи дослідження. Використано теоретичні методи дослідження: аналіз, синтез, класифікація, систематизація, емпіричні: опитування, соціометрія, статистичний метод обробки результатів. Результати дослідження. Проаналізовано показники професійних досягнень студентів-спортсменів ЗВО які надали змогу визначити кількісні і якісні відмінності у спортивних досягненнях, а також вплив спортивних ситуацій на формування особистісних якостей. Розглянуто результати навчальної і спортивної діяльності у формуванні соціально значущих якостей: соціальної активності, самостійності, впевненості у своїх здібностях. Висновки. Студентський спорт являє собою узагальнену категорію діяльності студентів у формі змагань і підготовки до них з метою досягнення граничних результатів у обраній спеціалізації. Результатом навчальної і спортивної діяльності студентів $€$ формування соціально значущих якостей: соціальної активності, самостійності, впевненості у своїх силах, честолюбства. Формування особистісних якостей студентів вищого навчального закладу під час спортивних занять в межах експерименту складає сукупність концептуальних положень і створення відповідних педагогічних умов. Доведено, що створені педагогічні умови, а саме постійні тренування та участь в змаганнях різного рівня сприяють підвищенню спортивної майстерності учасників команди та розвитку особистісних якостей студентів, сприятливих як для більшої їх успішності, як в певному виді спорту, так і в будь-якому виді діяльності в цілому.

Ключові слова: особистісні якості, студенти-спортсмени, соціометричний статус, рівень тривожності, спрямованість особистості, стрес-фактор.

Ukraine creates favorable conditions for the formation of a comprehensively developed, harmonious personality. In the new conditions, physical culture is an important state task.

In modern conditions, comprehensive and harmonious development of student youth is not only desirable but also necessary. Physical culture, achievement of high sports results should occupy one of the leading places in the work of higher education institutions. [4, p. 9]. 
Modern students, unfortunately, lead a sedentary lifestyle, face a number of difficulties related to the educational workload, and problems in interpersonal communication.

All this leads to a decrease in motivation or even lack of it to attend physical culture lessons and do sports, which in turn leads to a decrease in the level of health, mental and physical capacity of the entire population. In this regard, the formation of motivational interest in physical education and sports among students is of great importance.

Undoubtedly, this trend in the field of education raises the role of physical culture, which today is seen as an important means of preventing not only various diseases, but also the spread of harmful tendencies and habits among young people (drug addiction, alcoholism), constructive leisure time, fighting with the most acute challenge of our time: hypodynamia. This approach increases and complicates the tasks assigned to the relevant subject both within the secondary school and at higher educational institutions.

The analysis of the current curricula and programs in physical culture at higher educational institutions prove that the growth of the objective need of society in the formation of a physically active generation of future professionals is not reflected in them. Compared to other disciplines, the subject of "Physical Culture» is given the least number of hours.

However, experience has shown that the result of this subject in the structure of training remains high and tends to increase further. Today, young people have fewer opportunities to engage in physical culture for interests (reduction of sports sections, clubs), in addition, students often can not only enter, but will still work in their spare time. In addition, new types of learning appear in society (for example, on a distance basis), where the subject of physical culture is not taught at all.

But there is another trend which indicates that there is a trend of professional sports within higher educational institutions, which is manifested in the fact that in some universities there are sports teams of students who under the guidance of coaches of the Department of Physical Culture achieve their success in various sports and enter the level of professional sports.

As it is known, competitions are the essence of both mass and professional sports, they implement the main motivation of sports that is to achieve the highest results [2].

\section{Materials and methods of research}

The aim of the study is to theoretically substantiate and experimentally test the conditions for the formation of personal qualities of students of higher educational institutions under the conditions of their active participation in sports competitions.
The tasks of the study, aimed at achieving this goal, are:

1) introduction of a personality-oriented approach to the organization of training sessions;

2) involvement of students of higher educational institutions in systematic participation in training and sports competitions of different levels, which will increase the level of their skills and, accordingly, self-confidence;

3) stimulating students to focus on solving intra-group (team) tasks;

4) ensuring the moral and psychological climate in the team of students, which will change their social status and interpersonal relationships in the group (team).

Research methods: theoretical: analysis, synthesis, classification, systematization; empirical methods: surveys, testing, sociometry, statistical method of processing results.

Methods used in the study: questionnaire 'Situations of competition (stress factors)' by K. Frester [9]; method of diagnosing self-assessment of anxiety by Ch.D. Spielberger and J.L. Khanina [12]; methods of personality orientation in the activities by V. Smekal, M. Kucher [11]; sociometry was used in order to determine the sociometric status of students in a sports team [11].

To conduct an experimental study, a national basketball team of student youth was involved that studies at different faculties of Oles Honchar Dnipro National University, and participates in professional sports competitions at multiple levels. They formed an experimental group of 19 people (men). The age of the subjects is from 18 to 21 years. The control group consisted of 2 nd year students of the Faculty of Economics 18 people (men) aged $18-19$ years, who attend physical education classes on schedule and do not participate in competitions outside the university.

The difference in professional achievement indicators will allow to determine quantitative and qualitative differences in their sports achievements, as well as to determine the impact of sports situations on the formation of personal qualities (activity orientation, level of personal anxiety, sociometric status, stress factors) of studentsathletes at higher educational institutions.

Stages of research. At the first (formative) stage (February - April 2019) the problem, object and subject of research, purpose, and tasks were determined. A theoretical search was conducted, the main conceptual ideas were outlined. The methodical base of the research was concretized (methods, contingent of subjects, content, organization and procedures of the formative experiment). Also, the formative stage of experiment was carried out, the received results were processed and analyzed.

The second (formative) stage was to purposefully organize and conduct training sessions (according to 
the author's method) and involve students (national basketball team of Oles Honchar National University, Dnipro) to participate in sports competitions at different levels (at the university level, as well as district, city and regional scale).

At the third (control) stage (October-November 2019) a repeated study was conducted, the results of the formative experiment were summarized and analyzed in comparison with the control groups which allowed to determine the effectiveness of involving students of higher educational institutions in competitive activities and their impact on the formation of personal qualities of students-athletes.

\section{Results of the research}

To study the personal qualities of students participating in sports competitions, we identify the following features:

1) stress factors that occur in competitive activities and affect the sports result;

2) the orientation of the personality of athletes in activities that indicate their general life orientation;

3 ) the level of anxiety as a quality of personality (personal anxiety).

4) their sociometric status in teams which reflects the interpersonal relationships of people with others.

Also, the level of mastery of students-athletes of higher educational institutions was taken into account. These are the average values of the sums of assessment of athletes' own skills and assessment of their skills of coaches.

At the formative stage, we conducted a study of personal qualities of student youth, which is part of the national basketball team of Oles Honchar Dnipro National University, Dnipro (experimental group) and student youth of the 2 nd year students of the Faculty of Economics who were included in the control group by all methods.

The results obtained by all methods of the experimental and control groups are presented in the summary tables (4 and 5).

Analyzing the percentage of the impact of competition situations on the result, in the experimental group (student members of the basketball team), the percentage of those who are most negatively affected by competition situations is $32 \%$ (6 people); with an average degree of negative impact of competition situations $47 \%$ (9 studentsathletes), $21 \%$ (4 young athletes) are marked by the fact that competition situations have the least impact on their outcome.

Also, in the control group, where students do not play sports, $55.6 \%$ (10 students) have a high level of negative impact of competition situations on their results, and $44.4 \%$ ( 8 students) have an average level of negative impact of competition situations on their result. In addition, there is no student who has a low level of negative impact of competition situations on their outcome.
Table 1 - The results of the study of the negative impact of competition situations on the results of student youth of the experimental and control groups

\begin{tabular}{|l|l|l|l|l|}
\hline & \multicolumn{2}{|c|}{$\begin{array}{c}\text { Experimental group } \\
\text { (student-athletes) }\end{array}$} & \multicolumn{2}{|c|}{$\begin{array}{c}\text { Control group } \\
\text { (non-sports students) }\end{array}$} \\
\hline $\begin{array}{l}\text { High level of } \\
\text { negative impact } \\
\text { of competition } \\
\text { situations }\end{array}$ & 6 people & $32,0 \%$ & 10 people & $55,5 \%$ \\
\hline $\begin{array}{l}\text { Average level of } \\
\text { negative impact } \\
\text { of competition } \\
\text { situations }\end{array}$ & 9 people & $47,0 \%$ & 8 people & $44,4 \%$ \\
\hline $\begin{array}{l}\text { Low level of } \\
\text { negative impact } \\
\text { of competition } \\
\text { situations }\end{array}$ & 4 people & $21,0 \%$ & 0 people & $0,0 \%$ \\
\hline
\end{tabular}

Thus, it can be seen that students who play sports have a less expressed negative impact of competition situations on the outcome of competitions, and the vast majority of students-athletes experience an average and low level of impact of competition situations. In the group of students who do not play sports, the vast majority of students experience a high level of negative impact of competition situations on the results of their activities.

Comparative percentage analysis of the obtained results of the level of personal anxiety is presented in table 2 .

Table 2 - The comparative analysis of indicators of personal anxiety of students of the experimental and control groups (\%)

\begin{tabular}{|l|c|c|c|}
\hline \multirow{2}{*}{\multicolumn{1}{|c|}{ Researched }} & \multicolumn{3}{|c|}{ Level of anxiety } \\
\cline { 2 - 4 } & low & average & high \\
\hline Experimental group & $3-15,8$ & $11-58,0$ & $5-26,2$ \\
\hline Control group & $0-0$ & $10-55,6$ & $8-44,4$ \\
\hline
\end{tabular}

Judging by the table 2 , it can be noted that in the basketball team of students-athletes there is a lower percentage of the researched with a high level of anxiety $(26.2 \%)$ compared to students who do not play sports (44.4\%). Students-athletes also show a certain advantage in the indicators of the average level of personal anxiety (58.0\%) compared to students who do not play sports (55.6\%). $15.8 \%$ of students-athletes possess a low level of personal anxiety.

It is significant that students who do not play sports do not show a low level of personal anxiety, and in general they are dominated by average and high levels of personal anxiety.

The graphic representation of the distribution of levels of personal anxiety of students-athletes (experimental) and control group are presented on the Fig. 1 and 2 . 


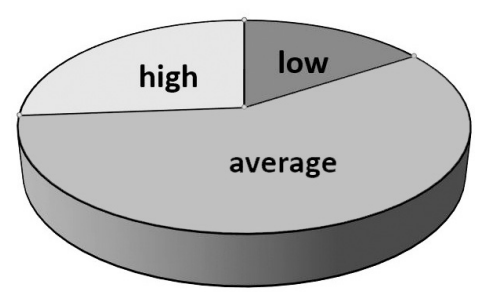

Fig. 1 The results of the distribution of levels of personal anxiety of students-athletes of the basketball team of Oles Honchar Dnipro National University

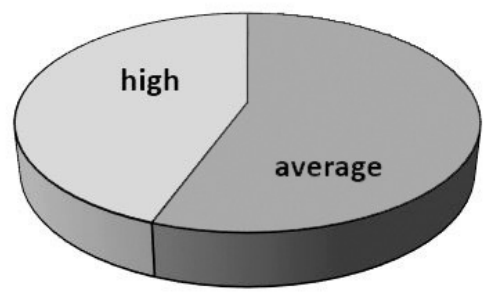

Fig. 2 Distribution of the levels of personal anxiety of Oles Honchar Dnipro National Univeristy who do not play sports

Thus, the preliminary conclusion of this analysis is the conclusion that under the conditions of participation of students-athletes in competitions at different levels, they have mostly low and average levels of personal anxiety. Also, students who do not play sports have mostly high and average levels of personal anxiety.

Regarding the results obtained by the method of diagnosis of personality orientation by V. Smekal, M. Kuchera (orientation questionnaire), the processing of the results showed that the dominant focus of students-athletes is focus on themselves (OT) $47.4 \%$ (9 people), focus on interaction (I), and on tasks $(\mathrm{T})$ have the same manifestation $26.3 \%$ (5 people). In the control group, the predominant focus is focus on themselves (OT) $50 \%$ (9 people), focus on interaction is $16.7 \%$ ( 3 people), and focus on tasks (OT) is $33.3 \%$ (6 people). Comparative characteristics of the types of orientation of students-athletes of the experimental and control groups are presented in the table 3.

Table 3- The comparative analysis of the indicators of the dominant orientation of students-athletes of the experimental and control groups (\%)

\begin{tabular}{|l|c|c|c|}
\hline \multirow{2}{*}{ Experimental group } & \multicolumn{3}{|c|}{ Type of orientation } \\
\cline { 2 - 4 } & OT & I & T \\
\hline Experimental group & $9-47,4$ & $5-26,3$ & $5-26,3$ \\
\hline Control group & $9-50,0$ & $3-16,7$ & $6-33,3$ \\
\hline
\end{tabular}

Processing the results of sociometry revealed that in the team of athletes of the basketball team at the beginning of the study, the social status of team members was distributed as follows: 'high flyers' $37 \%$ (7 people); 'popular' $27 \%$ (5 people); 'accepted' $19 \%$ (3 people); 'isolated' - 0 (0 people), 'neglected' $17 \%$ (3 people). Social statuses in the group of students who do not play sports are distributed as follows: 'high flyers' $31 \%$ (6 people); 'popular' $5 \%$ (1 person); 'accepted' $16 \%$ (3 people); 'isolated' $21 \%$ (4 people); 'neglected' $27 \%$ (5 people).

Table 4 - The summary table of the results of research of personal qualities of students-athletes of a basketball team of Oles Honchar National University at the formative stage by all methods

\begin{tabular}{|c|c|c|c|c|c|c|c|}
\hline Researched & $\begin{array}{l}\text { Mastery } \\
\text { (points) }\end{array}$ & Level of anxiety & Self-focus & $\begin{array}{l}\text { Focus on } \\
\text { interaction }\end{array}$ & $\begin{array}{l}\text { Focus } \\
\text { on the task }\end{array}$ & $\begin{array}{l}\text { The degree of influence } \\
\text { of situations on the result }\end{array}$ & $\begin{array}{c}\text { Sociometric } \\
\text { status }\end{array}$ \\
\hline & & & OT & 1 & $T$ & & \\
\hline 1 & 7 & $28-$ low & 26 & 29 & $35+$ & $25-$ low & 1.1 \\
\hline 2 & 6 & 34 - average & 27 & $33+$ & 30 & 28 - average & 0.47 \\
\hline 3 & 5 & 39 - average & 24 & 26 & $40+$ & $20-$ low & 0.9 \\
\hline 4 & 7 & 34 - average & 27 & 25 & $38+$ & 32 - average & 0.53 \\
\hline 5 & 6 & $28-$ low & 27 & $33+$ & 30 & 30 - average & 0.5 \\
\hline 6 & 6 & $30-$ low & 19 & 32 & $39+$ & $25-$ low & 0.53 \\
\hline 7 & 5 & 34 -average & 24 & 31 & $35+$ & 34 - average & 0.4 \\
\hline 8 & 7 & 34 - average & 31 & $33+$ & 26 & $46-$ high & 0.2 \\
\hline 9 & 3 & $46-$ high & $37+$ & 27 & 30 & 37 - average & 0.2 \\
\hline 10 & 4 & 41 - average & $34+$ & 28 & 28 & 27 - average & 0.2 \\
\hline 11 & 4 & 42 - average & $35+$ & 30 & 25 & $44-$ high & 0 \\
\hline 12 & 4 & $50-$ high & $41+$ & 25 & 24 & 46 - high & -1.27 \\
\hline 13 & 5 & $50-$ high & $44+$ & 22 & 24 & 44 -high & -0.3 \\
\hline 14 & 3 & 45 - average & $35+$ & 30 & 25 & 47 - high & -0.3 \\
\hline 15 & 3 & $46-$ high & $39+$ & 24 & 27 & 32 - average & -0.2 \\
\hline 16 & 3 & 41 - average & 30 & $34+$ & 26 & $45-$ high & -0.13 \\
\hline 17 & 2 & 31 - average & $36+$ & 28 & 26 & 27- average & 0 \\
\hline 18 & 3 & $39-$ high & 27 & $33+$ & 30 & 31 - average & 0 \\
\hline 19 & 2 & 46 - high & $32+$ & 29 & 28 & $20-$ low & 0 \\
\hline$\Sigma$ & 85 & 738 & 9 & 5 & 5 & 640 & \\
\hline $\mathrm{X}$ av. & 4,5 & 38,8 - average & & & & 33,7 - average & \\
\hline
\end{tabular}


Table 5 - The summary table of the results of the research of personal qualities of the control group of students of Oles Honchar Dnipro National University at the formative stage by all methods

\begin{tabular}{|c|c|c|c|c|c|c|c|}
\hline Researched & $\begin{array}{l}\text { Mastery } \\
\text { (points) }\end{array}$ & Level of anxiety & Self-focus & $\begin{array}{l}\text { Focus on } \\
\text { interaction }\end{array}$ & $\begin{array}{l}\text { Focus on the } \\
\text { task }\end{array}$ & $\begin{array}{c}\text { The degree of influence of } \\
\text { situations on the result }\end{array}$ & $\begin{array}{l}\text { Sociometric } \\
\text { status }\end{array}$ \\
\hline & & & OT & 1 & $T$ & & \\
\hline 1 & 3 & $52-$ high & 23 & 26 & $38+$ & 57 - high & 1.1 \\
\hline 2 & 2 & $52-$ high & 27 & 24 & $37+$ & $51-$ high & 0.47 \\
\hline 3 & 4 & $62-$ high & 19 & $37+$ & 21 & 27 - average & 0.9 \\
\hline 4 & 2 & 32 - average & 30 & 23 & $36+$ & 37 - average & 0.53 \\
\hline 5 & 3 & $46-$ high & $35+$ & 26 & 21 & 31 - average & 0.5 \\
\hline 6 & 4 & 45 - average & $34+$ & 24 & 27 & $55-$ high & 0.53 \\
\hline 7 & 5 & 35 - average & $36+$ & 28 & 24 & $44-$ high & 0.4 \\
\hline 8 & 3 & 34 - average & $38+$ & 21 & 26 & $44-$ high & 0.2 \\
\hline 9 & 3 & $31-$ average & $33+$ & 26 & 23 & 52 -high & 0.2 \\
\hline 10 & 4 & 42 - average & $35+$ & 27 & 19 & 36 - average & 0.2 \\
\hline 11 & 4 & 33 - average & 22 & 19 & $31+$ & 30 - average & 0 \\
\hline 12 & 4 & $52-$ high & $33+$ & 22 & 20 & $57-$ high & -1.27 \\
\hline 13 & 2 & $52-$ high & 20 & $33+$ & 27 & 51 - high & -0.3 \\
\hline 14 & 3 & $62-$ high & 27 & 24 & $36+$ & 27 - average & -0.3 \\
\hline 15 & 3 & 32 - average & 24 & $36+$ & 28 & 37 - average & -0.2 \\
\hline 16 & 3 & $46-$ high & $36+$ & 20 & 28 & 31 - average & -0.13 \\
\hline 17 & 2 & 45 - average & $38+$ & 25 & 25 & $55-$ high & 0 \\
\hline 18 & 3 & 35 - average & 24 & 22 & $34+$ & $44-$ high & 0 \\
\hline$\Sigma$ & 59 & 787 & 9 & 3 & 6 & 766 & \\
\hline $\mathrm{X}$ av. & 3,1 & 43,7 - average & & & & 42,6 - average & \\
\hline
\end{tabular}

\section{Discussion}

Research shows that young people who are actively involved in physical education and sports, study and work with better results, more fully reveal their abilities. Their ability to work is $20-30 \%$ higher, and the incidence, especially of colds, is much lower than others.

It is necessary to separate mass and professional sports since their tasks are slightly different: mass sports are needed to support people in physical shape, to satisfy the owner, and professional is the main activity of a sportsman. It is characterized not only by the presence of professional sports activities, but also by the presence of significant physical and psychological stress. It should be noted that modern sport is not just a struggle with muscles, but also with nerves. Therefore, special attention should be paid to the psychological training of athletes in higher education [3]. We believe that sports competitions are a subjective interpretation of the objective reality by athletes.

That is, it is a unity of objective, relatively independent of athletes, which occurs in their activities during the competition, and subjective, which is reflected in the peculiarities of perception due to individual psychological characteristics of the personality of student youth $[4 ; 5]$.

Analyzing the results obtained by the method of "Competitive situations» (stress factors) by K. Frester, it is seen that in the experimental group, the generalized negative impact of competition situations on the result is 33.7 points, which corresponds to the average level of manifestation, and in in the control group, the generalized indicator of negative impact is 42.6 points, which also corresponds to the average level but its highest manifestation (tables 4 and 5).

Analyzing the results obtained by the method of diagnosis of self-assessment of personal anxiety by Ch. D. Spielberger, J. L. Khanina, it is observed that there are differences in performance between studentsathletes (Tables 4 and 5).

The average level of personal anxiety in the experimental group is 38.8 points, and in the control group 43.7 points, which in both cases corresponds to the average level, but for students-athletes the level of anxiety is lower than for students who do not play sports. Note that students of the basketball team of the Oles Honchar Dnipro National University at the formative stage of the research showed higher indicators in mastery: the average indicators were 4.5 points compared to 3.1 points in the group of students who do not play sports (tables 4 and 5).

\section{Conclusions}

The conducted work gives an opportunity to state the following: the motives that make students engage in Physical Education depend on the following: the desire to improve physical fitnes, optimize weight, improve shape, relieve fatigue and increase efficiency, bring up a good 
manner, culture of movements, achieve sports success, bring up will, character, purposefulness, spend free time rationally, etc.

The difference in the indicators of professional achievements of students-athletes at higher educational institutions allowed to determine quantitative and

\section{Джерела та література}

1. Абсалямов Т. М. (2003). Роль и место науки в подготовке спортсменов высокого класса. Теория и практика физической культуры, 10, 17-20.

2. Бундзен П. В. (2000). Современные тенденции в развитии технологий психической подготовки спортсменов. Ежегодный научный вестник. КАФК им. П.Ф. Лесгафта. СПб. 40-44.

3. Гогунов Е. Н. Мартьянов Б. И. (2004). Психология физического воспитания и спорта: учебн. пособие для студ. высш. пед. учеб. заведений. М.: Издательский центр «Академия». 224 с.

4. Гордон С. М. (2004). Исследование оценки психической готовности к соревновательной деятельности спортсменов. Теория и практика физической культуры, 2, 46-49.

5. Гордон С. М. (2003). Оценка личности спортсменов разных специализаций и квалификаций. Теория и практика физической культуры, 2, 24-28.

6. Кизько А. П. (2004). Принципиальные вопросы корректности результатов экспериментального исследования в области физического воспитания и спорта. Теория и практика физической культуры и спорта, 1, 59-62.

7. Козлов Е. Г. (2002). Постановка проблемы готовности к соревнованию в спорте. Теория и практика физической культуры, 4, 33-36.

8. Маріонда І. І. (2018). Формування мотивації студентів до занять фізичною культурою. Актуальні питання вдосконалення системи фізичного виховання і спортивної роботи у вищій школі: зб. наук. пр. матеріали I наук.-практ. конф. з міжнародною участю, м. Ужгород, 19-20 квітня 2018 р. Ужгород, 2018. 123 с.

9. Методика психодиагностики в спорте (1990) / под ред. В. Л. Марищука, Ю. М. Блудова, В. А. Плахтиенко. М.: Просвещение, 256 с.

10. Мордвінцев Г. О. (2018). Висвітлення сучасного стану і проблем фізичного виховання студентів та напрямків вдосконалення розвитку фізичного виховання у навчальному процесі ВН3. Актуальні питання вдосконалення системи фізичного виховання і спортивної роботи у вищій школі: зб. наук. пр. матеріали I наук.практ. конф. з міжнародною участю, м. Ужгород, 19-20 квітня 2018 р. Ужгород, 37-38.

11. Практикум по спортивной психологии (2003) / под ред. И. П. Волкова. Питер: СПБ. 60 с.

12. Практическая психодиагностика: методики и тесты: уч. пос. (2001) / под ред. Д. Я. Райгородского. Самара: Издательский Дом «Бахрам-м», 672 с.

13. Фурдуй С. Б., Ніфака Я. М. (2018). Роль фізичної культури в процесі соціалізації студентської молоді. Науковий журнал «Молодий вчений», 1 (53), 395 с. qualitative differences in their sports achievements, and also clarified the influence of sports situations on the formation of personal qualities (activity orientation, level of personal anxiety, sociometric status).

Conflict of interests. The authors declare no interest conflict.

\section{References}

1. Absalyamov, T. M. (2003). Rol' i mesto nauki v podgotovke sportsmenov vysokogo klassa [The role and place of science in training high-class athletes]. Teoriya i praktika fizicheskoi kul'tury, 10, 17-20 [in Russian].

2. Bundzen, P. V. (2000). Sovremennye tendentsii v razvitii tekhnologii psikhicheskoi podgotovki sportsmenov [Current trends in the development of technologies for the mental preparation of athletes]. Ezhegodnyi nauchnyi vestnik. KAFK im. P. F Lesgafta. SPb. 40-44 [in Russian].

3. Gogunov, E. N., Mart yanov, B. I. (2004). Psikhologiya fizicheskogo vospitaniya i sporta [Psychology of physical education and sports]: uchebn. posobie dlya stud. vyssh. ped. ucheb. zavedenii. M.: Izdatel'skii tsentr "Akademiya”. 224 [in Russian].

4. Gordon, S. M. (2004). Issledovanie otsenki psikhicheskoi gotovnosti k sorevnovatel 'noi deyatel'nosti sportsmenov [Study of the assessment of mental readiness for competitive activity of athletes]. Teoriya $i$ praktika fizicheskoi kul 'tury, 2, 46-49 [in Russian].

5. Gordon, S. M. (2003). Otsenka lichnosti sportsmenov raznykh spetsializatsii i kvalifikatsii [Assessment of the personality of athletes of different specializations and qualifications]. Teoriya $i$ praktika fizicheskoi kul tury, 2, 24-28 [in Russian].

6. Kiz`ko, A. P. (2004). Printsipial’nye voprosy korrektnosti rezulıtatov ehksperimental'nogo issledovaniya $v$ oblasti fizicheskogo vospitaniya i sporta [Fundamental questions of the correctness of the results of experimental research in the field of physical education and sports]. Teoriya i praktika fizicheskoi kul'tury i sporta, 1, 59-62 [in Russian].

7. Kozlov, E.G. (2002). Postanovka problemy gotovnosti k sorevnovaniyu $v$ sporte [Statement of the problem of readiness preparedness for competition in sport]. Teoriya i praktika fizicheskoi kul'tury, 4, 33-36. [in Russian].

8. Marionda, I. I. (2018). Formuvannya moty vaciyi studentiv do zanyat` fizy'chnoyu kul'turoyu [Formation of students' motivation for physical education]. Aktual 'ni py'tannya vdoskonalennya sy 'stemy' fizy'chnogo vy`xovannya i sporty 'vnoyi roboty' $u$ vy'shhij shkoli: zb. nauk. pr. materialy' I nauk.-prakt. konf. z mizhnarodnoyu uchastyu, m. Uzhgorod, 19-20 kvitnya 2018 r. Uzhgorod, 123 [in Ukrainian].

9. Metodika psikhodiagnostiki v sporte (1990) [Methods of psychodiagnostics in sports] / pod red. V. L. Marishchuka, Yu. M. Bludova, V. A. Plakhtienko. M.: Prosveshchenie. 256 [in Russian].

10. Mordvincev, G. O. (2018). Vy`svitlennya suchasnogo stanu i problem fizy`chnogo vy`xovannya studentiv ta napryamkiv vdoskonalennya rozvy`tku fizy`chnogo vy`xovannya u navchal'nomu procesi VNZ. [Lighting of the current state and problems of physical education of students and directions of improvement of development of physical educational in educational process of high school]. Aktual 'ni py 'tannya vdoskonalennya sy`stemy` fizy`chnogo vy`xovannya i sporty vnoyi roboty ' $u$ vy`shhij shkoli: zb. nauk. pr. materialy` I nauk.-prakt. konf. z mizhnarodnoyu uchastyu, m. Uzhgorod, 19-20 kvitnya. Uzhgorod. 37-38 [in Ukrainian].

11. Praktikum po sportivnoi psikhologii (2003) [Workshop on sport psychology] / pod red. I. P. Volkova. Piter: SPB. 60 [in Russian].

12. Prakticheskaya psikhodiagnostika: metodiki i testy [Practical psychodiagnostics: methods and tests]: uch. pos. (2001) / pod red. D. Ya. Raigorodskogo. Samara: Izdatel'skii Dom "Bakhram-M". 672 [in Russian].

13. Furduj, S. B., Nifaka Ya. M. (2018). Rol` fizy`chnoyi kul’tury` v procesi socializaciyi students'koyi molodi [The role of physical culture in the process of socialization of student youth]. Naukovy`j zhurnal "Molody 'j vcheny 'j", 1 (53), 395 [in Ukrainian]. 